\title{
EFFECT OF A PHOTOCATALYTIC COMPOSITE COUPLED WITH POTAMOGETOR CRISPUS ON CONTROL SEDIMENT PHOSPHORUS
}

\author{
VPLIV FOTOKATALITIČNEGA KOMPOZITA, ZDRUŽENEGA S \\ KODRAVIM DRISTAVCEM, NA KONTROLO ODLAGANJA \\ FOSFORJA
}

\author{
Yi Zhang ${ }^{1 *}$ Yunli Liu ${ }^{1,2}$, Feng Luo ${ }^{3}$, Zisen Liu ${ }^{1}$, Yilingyun Zou ${ }^{1,2}$, Lingwei Kong ${ }^{4}$, \\ Dong $\mathrm{Xu}^{1}{ }^{*}$, Zhenbin Wu ${ }^{1}$ \\ ${ }^{1}$ State Key Laboratory of Freshwater Ecology and Biotechnology, Institute of Hydrobiology, Chinese Academy of Sciences, \\ Wuhan 430072, China \\ ${ }^{2}$ University of Chinese Academy of Sciences, Beijing 100049, China \\ ${ }^{3}$ School of Resources and Environmental Engineering, Wuhan University of Technology, Wuhan 430070, China \\ ${ }^{4}$ Environmental Research and Design Institute of Zhejiang Province, Hangzhou 310007, China
}

Prejem rokopisa - received: 2019-07-10; sprejem za objavo - accepted for publication: 2019-12-23

doi: $10.17222 /$ mit.2019.267

The treatment efficiency of phosphorus (P) in a sediment with the joint action of a new photocatalytic composite $\mathrm{Sr}_{-} \mathrm{TiO} / \mathrm{PCFM}_{2}$ and submerged macrophyte was studied for the first time in Donghu Lake, Wuhan, China. The results showed that $\mathrm{Sr}_{-} \mathrm{TiO}_{2} / \mathrm{PCFM}$ prepared by the sol-gel process exhibited a strong photocatalytic capacity. The dosage of $\mathrm{Sr}-\mathrm{TiO} / \mathrm{PCFM}$, irradiation, operation temperature, reaction time and $\mathrm{pH}$ were the principal factors affecting the removal of each sediment $\mathrm{P}$ forms by $\mathrm{Sr}-\mathrm{TiO}_{2} / \mathrm{PCFM}$. The synergistic effect of $\mathrm{Sr}_{-} \mathrm{TiO}_{2} / \mathrm{PCFM}$ and submerged macrophyte Potamogetor crispus on the sediment $\mathrm{P}$ under irradiation and control conditions showed that the removal rates of each $\mathrm{P}$ form have been further enhanced after irradiation. The unity of $\mathrm{Sr}-\mathrm{TiO}_{2} / \mathrm{PCFM}$ and Potamogeton crispus plays a more important role in removing the sedimental $\mathrm{P}$ than the summation of $\mathrm{Sr}-\mathrm{TiO}_{2} / \mathrm{PCFM}$ and Potamogeton crispus used separately under the irradiation conditions. The results suggested that the united technology of $\mathrm{Sr}_{-} \mathrm{TiO}_{2} / \mathrm{PCFM}$ and submerged macrophyte could be further applied to the treatment of endogenous $\mathrm{P}$ pollution in eutrophic lakes.

Keywords: $\mathrm{Sr}_{-} \mathrm{TiO}_{2} / \mathrm{PCFM}$, submerged macrophyte, synergistic effect, sediment $\mathrm{P}$ in all fractions, $\mathrm{P}$ removal

V jezeru Donghu v Wuhanu na Kitajskem so prvič študirali učinkovitost obdelave usedlin fosforja v povezavi z delovanjem fotokatalitičnega kompozita $\mathrm{Sr}_{-} \mathrm{TiO}_{2} / \mathrm{PCFM}$ v podvodnem rastlinju. Rezultati raziskave so pokazali, da ima $\mathrm{Sr}-\mathrm{TiO} / \mathrm{PCFM}$, pripravljen po Sol-Gel-postopku močno fotokatalitično kapaciteto. Doziranje $\mathrm{Sr}_{-} \mathrm{TiO}_{2} / \mathrm{PCFM}$, obsevanje, temperatura delovanja, reakcijski čas in $\mathrm{pH}$, so glavni faktorji, ki vplivajo na odstranitev fosforja iz vsake usedline z $\mathrm{Sr}_{-} \mathrm{TiO}_{2} / \mathrm{PCFM}$. Avtorji članka ugotavljajo, da je sinergistični učinek $\mathrm{Sr}_{-} \mathrm{TiO}_{2} / \mathrm{PCFM}$ in podvodnega rastlinja iz kodravega dristavca (Potamogetor crispus) na usedline fosforja pod vplivom obsevanja in pri kontroliranih pogojih dodatno pospešen po obsevanju. Skupno delovanje $\mathrm{Sr}_{-} \mathrm{TiO}_{2} / \mathrm{PCFM}$ in kodravega dristavca igra bolj pomembno vlogo pri odstranitvi usedlin fosforja, kot ločena uporaba vsakega

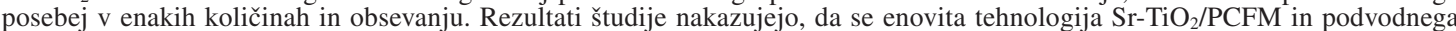
makrofita lahko uporablja tudi za obdelavo endogene onesnaženosti s fosforjem $v$ evtroficiranih jezerih, to je jezerih, $v$ katerih poteka pretiran proces razraščanja biomase (rastlinja, alg itd.).

Ključne besede: $\mathrm{Sr}-\mathrm{TiO}_{2} / \mathrm{PCFM}$, podvodne rastline (makrofit), sinergistični učinek, usedlina fosforja v vseh frakcijah, odstranitev fosforja

\section{INTRODUCTION}

Phosphorus (P) in lakes comes from two sources, i.e., the internal release of sediment and the external load. ${ }^{1,2}$ The accumulation of endogenous $\mathrm{P}$ in sediment can bring great potential risk to eutrophication. Lake sediments are considered to be the reservoir of $\mathrm{P}$, and the release of endogenous $\mathrm{P}$ in sediments is the main source of eutrophication, especially in shallow lakes. ${ }^{3,4}$

In nutrient-rich shallow lakes, the inputs of exogenous $\mathrm{P}$ will be brought under control through a variety of technologies. The internal P load becomes the decisive resource of overburden water $\mathrm{P}$ supply after con-

*Corresponding author's e-mail:

zhangyi@ihb.ac.cn (Yi Zhang), xudong@ihb.ac.cn (Dong Xu) trolling the input of external phosphorus load. ${ }^{5}$ Thus, it is very important to decrease the content of endogenous $\mathrm{P}$ and inhibit the release of endogenous $\mathrm{P}$ in sediments.

Various endogenous pollution-control strategies have been developed, such as dredging, ${ }^{6}$ oxidation treatment, physicochemical sedimentation, ${ }^{7-9}$ phytoremediation ${ }^{10,11}$ and in-situ sediment capping ${ }^{12,13}$ to reduce the release flux of P from sediment in eutrophic lakes. Submerged plants have certain inhibitory effects on sediment resuspension and $\mathrm{P}$ release, and uptake and absorb $\mathrm{P}$ from interstitial water and sediment, which is an applicable way to restore the eutrophic water ecosystem. ${ }^{14}$ However, the restoration process of $\mathrm{P}$ by plants is often affected by the growing period and surroundings, and single ecological technologies cannot be applied effect- 
ively. At present, a synergistic technology for control sediment $\mathrm{P}$ is urgently needed. ${ }^{5}$

Nano-titanium dioxide (nano- $\mathrm{TiO}_{2}$ ) has the advantages of high stability, low toxicity, large specific surface area and high catalytic efficiency, and is considered as one of the most practical candidate materials for environmental pollution control. ${ }^{15-18} \mathrm{Nano}^{-\mathrm{TiO}_{2}}$ thin films have become a hotspot because of their ease of recycling and separation.

In our previous studies, porous ceramic filter media (PCFM) was adopted as the carrier of the $\mathrm{TiO}_{2}$ film, and we found that the photocatalytic composite has a great potential to control the internal $\mathrm{P}$ pollution. While little is known about the remediation effect of sediment $\mathrm{P}$ in all fractions with the synergistic effect of nano- $\mathrm{TiO}_{2}$ and submerged macrophytes. To further enhance the single action of submerged macrophytes and nano- $\mathrm{TiO}_{2}$ on sediment $\mathrm{P}$ remediation, a $\mathrm{Sr}-\mathrm{TiO}_{2} / \mathrm{PCFM}$ ( $\mathrm{Sr}$ doped into $\mathrm{TiO}_{2}$ ) photocatalyst capable of responding to visible light was developed, and the removal effect of each sediment $\mathrm{P}$ forms with the joint effects of $\mathrm{Sr}-\mathrm{TiO}_{2} / \mathrm{PCFM}$ and submerged macrophyte were studied for the first time.

\section{EXPERIMENTAL PART}

\subsection{Study sites and sampling}

Donghu Lake is located to the northeast of Wuhan city, Hubei province, China. The sampling site $\left(30^{\circ} 33^{\prime} 04.9^{\prime \prime} \mathrm{N}, 114^{\circ} 21^{\prime} 07.1^{\prime \prime} \mathrm{E}\right)$ is located on the west side of Shuiguo Lake (one sub-lake of Donghu Lake), which is a serious eutrophication area. Surface sediment samples $(0-10 \mathrm{~cm})$ and PCFM were collected and obtained. 5,19

\subsection{P fractions}

$\mathrm{P}$ fractions were employed with the SMT harmonized protocol, containing five $\mathrm{P}$ forms: Fe/Al-P, Ca-P, OP, IP and TP. ${ }^{20}$ The operationally defined scheme was composed of five phosphorus forms: Fe/Al-P ( NaOH-extractable $\mathrm{P}, \mathrm{P}$ bound to $\mathrm{Al}, \mathrm{Fe}$ and $\mathrm{Mn}$ oxides and hydroxides), Ca-P ( $\mathrm{HCl}$-extractable $\mathrm{P}, \mathrm{P}$ associated with $\mathrm{Ca}$ ), organic P (OP), inorganic P (IP) and total P (TP). In a separate extraction, $\mathrm{HCl}$-extracted inorganic $\mathrm{P}$ (IP) and the residual were treated at $450{ }^{\circ} \mathrm{C}$ to decompose the organic matter and to release the $\mathrm{P}$ bound to organic matter (OP). TP concentration in sediments was determined by treating the sample at $450{ }^{\circ} \mathrm{C}$, followed by $\mathrm{HCl}$ extraction.

\subsection{Batch experiments}

\subsubsection{Adsorption experiments}

A certain amount of $\mathrm{Sr} / \mathrm{TiO}_{2}-\mathrm{PCFM}$ and $5 \mathrm{~g}$ of sediment samples were added and shaken for a period of time at different $\mathrm{pH}$ and temperatures for a stirring experiment. Chloroform $(0.1 \%)$ was added to inhibit the bacterial activity.

\subsubsection{Photocatalytic experiments}

The photoreactor system was made up of a quartz beaker reactor $(500 \mathrm{~mL})$, a nitrogen pump and a $125-\mathrm{W}$ high-pressure mercury lamp. $\mathrm{Sr} / \mathrm{TiO}_{2}-\mathrm{PCFM}$ and the sediment were put into a $250-\mathrm{mL} \mathrm{KCl}$ solution $(0.02 \mathrm{M})$. The suspension was irradiated under the high-pressure mercury lamp for $0.5 \mathrm{~h}$. The visible light was shone vertically into the solution and the distance between the illuminant and liquid level was $40 \mathrm{~cm}$, and the luminous flux was $1500 \mathrm{Lm}$.

\subsubsection{Phytoremediation experiments}

Potamogeton crispus was sampled from the Donghu Lake in Wuhan, China. Potamogeton crispus (approximately $20 \mathrm{~cm}$ in length) were planted in the polythene buckets with a layer of sediment on the bottom. ${ }^{5}$

\subsubsection{Combined experiments}

Potamogeton crispus (approximately $20 \mathrm{~cm}$ in length) was planted into the polythene buckets (diameter $45 \mathrm{~cm}$, height $60 \mathrm{~cm}$ ). A sediment sample of $8 \mathrm{~cm}$ in thickness and $\mathrm{Sr}-\mathrm{TiO}_{2} / \mathrm{PCFM}$ with a certain thickness were placed in each bucket after the Potamogeton crispus grew stable. The visible light was shone vertically into the solution and the distance between the illuminant and the liquid level was $50 \mathrm{~cm}$, the irradiation frequency was $2 \mathrm{~h} / \mathrm{d}$, and the control group was under outdoor conditions.

\section{RESULTS AND DISCUSSION}

\subsection{Sediment characteristics}

The characteristics and compositions of sediments in Donghu Lake are shown in Table 1. ${ }^{19}$ The grain size of the samples was almost less than $63 \mathrm{~mm}$, and the silt fraction (4-63 $\mathrm{mm})$ was the main one $(79.76 \%)$.

Table 1: Properties and chemical compositions of the sediment

\begin{tabular}{|c|c|c|}
\hline Properties & & Content \\
\hline \multirow{3}{*}{ Grain size $(\%)$} & $<4 \mu \mathrm{m}$ & $9.26 \pm 0.05$ \\
\cline { 2 - 3 } & $4-63 \mu \mathrm{m}$ & $79.76 \pm 0.62$ \\
\cline { 2 - 3 } & $63-400 \mu \mathrm{m}$ & $6.89 \pm 0.02$ \\
\hline \multirow{4}{*}{$\begin{array}{c}\text { Major element } \\
(w / \%)\end{array}$} & $\mathrm{SiO}_{2}$ & $49.58 \pm 0.56$ \\
\cline { 2 - 3 } & $\mathrm{Al}_{2} \mathrm{O}_{3}$ & $11.46 \pm 0.21$ \\
\cline { 2 - 3 } & $\mathrm{Na}_{2} \mathrm{O}$ & $23.57 \pm 0.38$ \\
\cline { 2 - 3 } & $\mathrm{CaO}_{1}$ & $12.64 \pm 0.16$ \\
\hline \multirow{2}{*}{$\mathrm{pH}$} & $\mathrm{Fe}_{2} \mathrm{O}_{3}$ & $5.14 \pm 0.05$ \\
\hline TOC $(\%)$ & & $7.39 \pm 0.20$ \\
\hline \multirow{3}{*}{$\begin{array}{c}\text { P fractions } \\
\left(\mathrm{mg} \mathrm{kg}^{-1}\right)\end{array}$} & & $5.22 \pm 0.06$ \\
\cline { 2 - 3 } & $\mathrm{Fe} / \mathrm{Al}-\mathrm{P}$ & $462 \pm 13$ \\
\cline { 2 - 3 } & $\mathrm{Ca}-\mathrm{P}$ & $105 \pm 5$ \\
\cline { 2 - 3 } & $\mathrm{IP}$ & $553 \pm 14$ \\
\cline { 2 - 3 } & $\mathrm{OP}$ & $773 \pm 6$ \\
\hline
\end{tabular}




\subsection{Preparation of $\mathrm{Sr} / \mathrm{TiO}_{2}-\mathrm{PCFM}$}

PCFM coated with a nano- $\mathrm{Sr} / \mathrm{TiO}_{2}$ film $\left(\mathrm{Sr} / \mathrm{TiO}_{2}-\right.$ PCFM) with a $\mathrm{TiO}_{2}$ content $11.5 \%(w / \%)$ was obtained as referred to in our previous research. ${ }^{19}$ TEM micrographs of the nano- $\mathrm{TiO}_{2}$ film (Figure 1a) shows that the film had good surface properties with an average particle size of $10-20 \mathrm{~nm}$. SEM photographs of the $\mathrm{Sr}^{-\mathrm{TiO}_{2}} /$ PCFM (fracture surface) (Figure 1b) show that the compact nano- $\mathrm{TiO}_{2}$ film was firmly loaded on the surface of the PCFM.

\subsection{Removal of sediment $\mathrm{P}$ with $\mathrm{Sr} / \mathrm{TiO}_{2}-\mathrm{PCFM}$ in stirring tests}

\subsubsection{Effect of dosage of $\mathrm{Sr} / \mathrm{TiO}_{2}-\mathrm{PCFM}$}

In order to study the effect of the amount on the removal of $\mathrm{P}$ in the sediments by $\mathrm{Sr} / \mathrm{TiO}_{2}-\mathrm{PCFM}$, tests were conducted under adsorption (no irradiation) and photocatalytic (irradiation) conditions. ${ }^{5}$ The related results are shown in Figure 2. The increase of the $\mathrm{Sr} / \mathrm{TiO}_{2}-\mathrm{PCFM}$ dosage increased the removal rate of the sediment $\mathrm{P}$ both under adsorption and photocatalytic conditions $(P<0.05)$. When the amount of $\mathrm{Sr} / \mathrm{TiO}_{2-}$ PCFM was 4-6 g, the increased trend of the removal quantity of sediment $\mathrm{P}$ flattens out. The removal quantity of each $\mathrm{P}$ forms (Ca-P, Fe/Al-P, IP, OP and TP) was $16 \mathrm{mg} / \mathrm{kg}, 188 \mathrm{mg} / \mathrm{kg}, 218 \mathrm{mg} / \mathrm{kg}, 70 \mathrm{mg} / \mathrm{kg}$ and $305 \mathrm{mg} / \mathrm{kg}$, respectively, as the dosage was $4 \mathrm{~g}$. Under photocatalytic conditions, the removal quantity of each $\mathrm{P}$ forms was $17 \mathrm{mg} / \mathrm{kg}, 228 \mathrm{mg} / \mathrm{kg}, 260 \mathrm{mg} / \mathrm{kg}, 84 \mathrm{mg} / \mathrm{kg}$ and $360 \mathrm{mg} / \mathrm{kg}$, respectively, and the corresponding removal rate was $16.2 \%, 52.2 \%, 47.4 \%, 49.7 \%$ and $46.7 \%$, respectively. It is clear that the removal amounts of each $\mathrm{P}$ form were increased after irradiating with a high-pressure mercury lamp $(P<0.05)$.

\subsubsection{Effects of reaction time}

The effects of reaction time on the $\mathrm{P}$ removal from the sediment by $\mathrm{Sr} / \mathrm{TiO}_{2}-\mathrm{PCFM}$ at $20 \pm 2{ }^{\circ} \mathrm{C}$ under adsorption (no irradiation) and photocatalytic (irradiation) conditions are presented in Figure 3. In Figure 3, under adsorption conditions, the removal quantities of each $\mathrm{P}$ form were increased rapidly within $4 \mathrm{~h}$, then continued to increase at a slow rate $(P<0.05)$. The removal quantity of each $P$ forms was $16 \mathrm{mg} / \mathrm{kg}, 190 \mathrm{mg} / \mathrm{kg}$,

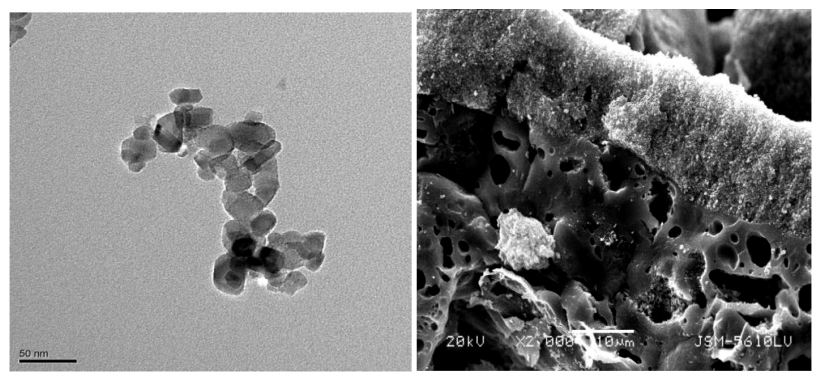

Figure 1: a) TEM micrographs of nano- $\mathrm{TiO}_{2}$ film and b) SEM photographs of $\mathrm{Sr}-\mathrm{TiO}_{2} / \mathrm{PCFM}$ (fracture surface)

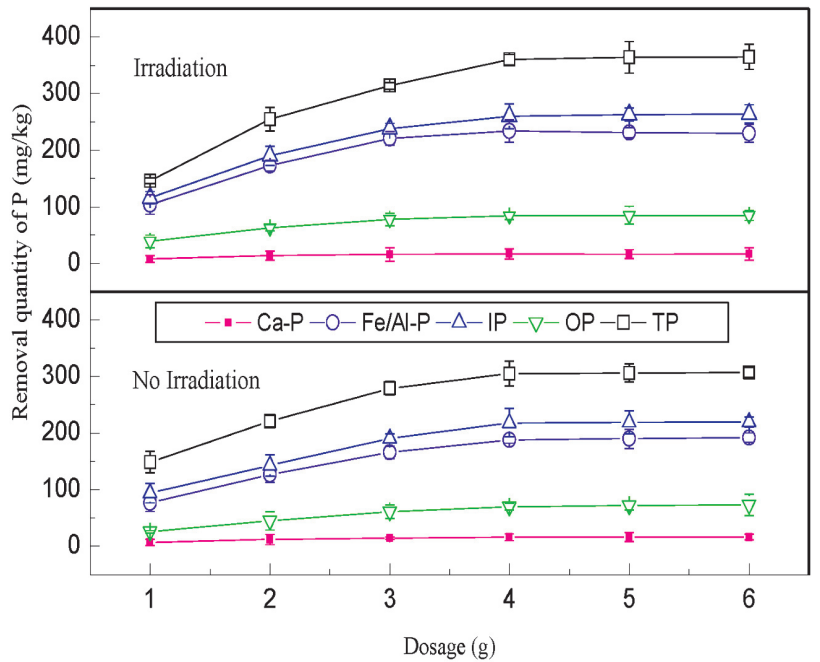

Figure 2: Effect of dosage of $\mathrm{Sr}-\mathrm{TiO}_{2} / \mathrm{PCFM}$ on $\mathrm{P}$ removal

$218 \mathrm{mg} / \mathrm{kg}, 72 \mathrm{mg} / \mathrm{kg}$ and $303 \mathrm{mg} / \mathrm{kg} / \mathrm{kg}$, respectively, as the reaction time was $8 \mathrm{~h}$.

Under photocatalytic conditions, the removal quantities of each $\mathrm{P}$ form were increased significantly in a short time and achieved the equilibrium within $4 \mathrm{~h}$. The removal quantity of each $\mathrm{P}$ form was $17 \mathrm{mg} / \mathrm{kg}$, $229 \mathrm{mg} / \mathrm{kg}, 262 \mathrm{mg} / \mathrm{kg}, 86 \mathrm{mg} / \mathrm{kg}$ and $360 \mathrm{mg} / \mathrm{kg}$, respectively, correspondingly, the removal rate was $16.2 \%$, $49.6 \%, 47.4 \%, 49.7 \%$ and $46.7 \%$, respectively.

\subsubsection{Effects of $p H$ on $P$ removal}

The operation $\mathrm{pH}$ not only influences adsorption performance, it also influences the photocatalytic effect. $^{21,22}$ The solution $\mathrm{pH}$ affects the adsorption effect by changing the surface properties of the adsorbents. Meanwhile, the stepwise reduction potential of the phosphate, and the valence band and conduction band of $\mathrm{TiO}_{2}$ change as the $\mathrm{pH}$ changes. ${ }^{23}$ Thus, the $\mathrm{pH}$ was viewed as an important factor in the process of Sr- $\mathrm{TiO}_{2} / \mathrm{PCFM}$ treating sediment $\mathrm{P}$.

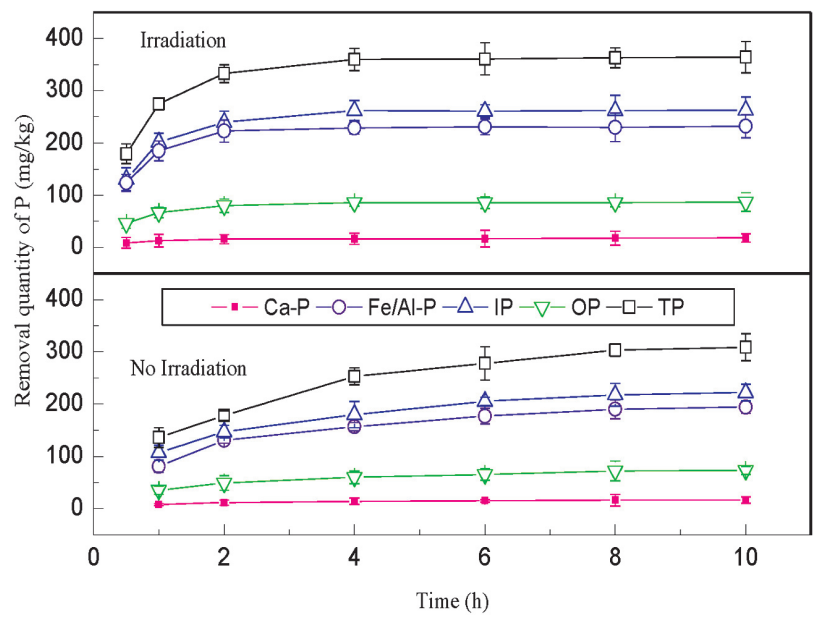

Figure 3: Effect of reaction time on sediment $\mathrm{P}$ removal 
The related results are presented in Figure 4. The adsorption efficiency of sediment $\mathrm{P}$ in all fractions was the highest under the conditions of adsorption with strong acid. The adsorption amount of each $\mathrm{P}$ form from the sediment at $\mathrm{pH} 2$ was $19 \mathrm{mg} / \mathrm{kg}, 207 \mathrm{mg} / \mathrm{kg}$, $243 \mathrm{mg} / \mathrm{kg}, 78 \mathrm{mg} / \mathrm{kg}$ and $340 \mathrm{mg} / \mathrm{kg}$, respectively. The corresponding adsorption rate was up to $18.1 \%, 44.8 \%$, $43.9 \%, 45.1 \%$ and $44.1 \%$, respectively. The adsorption amount of each $\mathrm{P}$ form decreased at different levels as the $\mathrm{pH}$ increased from 2 to $12(P<0.05)$. The possible reason was that the isoelectric point $\mathrm{pH}$ of the nano $\mathrm{TiO}_{2}$ was 6.25 , the lower $\mathrm{pH}$ induced an increase of the surface positive charge on $\mathrm{Sr}-\mathrm{TiO}_{2} / \mathrm{PCFM}$, which was beneficial to the adsorption of phosphate ions in sediments.

Under photocatalytic conditions, the removal effect of the sediment $\mathrm{P}$ in all fractions was influenced more obviously by $\mathrm{pH}(P<0.05)$. When $\mathrm{pH}=2$, the removal quantity of each $\mathrm{P}$ form was $20 \mathrm{mg} / \mathrm{kg}, 256 \mathrm{mg} / \mathrm{kg}$, $292 \mathrm{mg} / \mathrm{kg}, 93 \mathrm{mg} / \mathrm{kg}$ and $403 \mathrm{mg} / \mathrm{kg}$, respectively, correspondingly, the removal rate was $19.0 \%, 55.4 \%$, $52.8 \%, 53.8 \%$ and $52.3 \%$, respectively. The removal quantities of each P form were $3 \mathrm{mg} / \mathrm{kg}, 28 \mathrm{mg} / \mathrm{kg}$, $32 \mathrm{mg} / \mathrm{kg}, 9 \mathrm{mg} / \mathrm{kg}$ and $43 \mathrm{mg} / \mathrm{kg}$, respectively, higher than in the neutral condition. The possible reason was that the stepwise reduction potential of phosphate in acidic conditions was higher than that in neutral and alkaline, which was relatively easy to be reduced through photodegradation. While the in-depth mechanisms need to be further studied and explored.

\subsubsection{Influence of operation temperature}

Temperature is generally regarded to be an important factor in adsorption and photocatalytic processes. ${ }^{24,25}$ The removal of sediment $\mathrm{P}$ by $\mathrm{Sr} / \mathrm{TiO}_{2}-\mathrm{PCFM}$ was studied at different temperatures, ranging from $5{ }^{\circ} \mathrm{C}$ to an extreme high temperature $70{ }^{\circ} \mathrm{C}$ under adsorption and photocatalytic conditions (Figure 5). As seen from Figure 5, the temperature has an impact on the removal of sediment $\mathrm{P}$ in the both conditions $(P<0.05)$. The removal amounts of each $\mathrm{P}$ form increased as the temperature

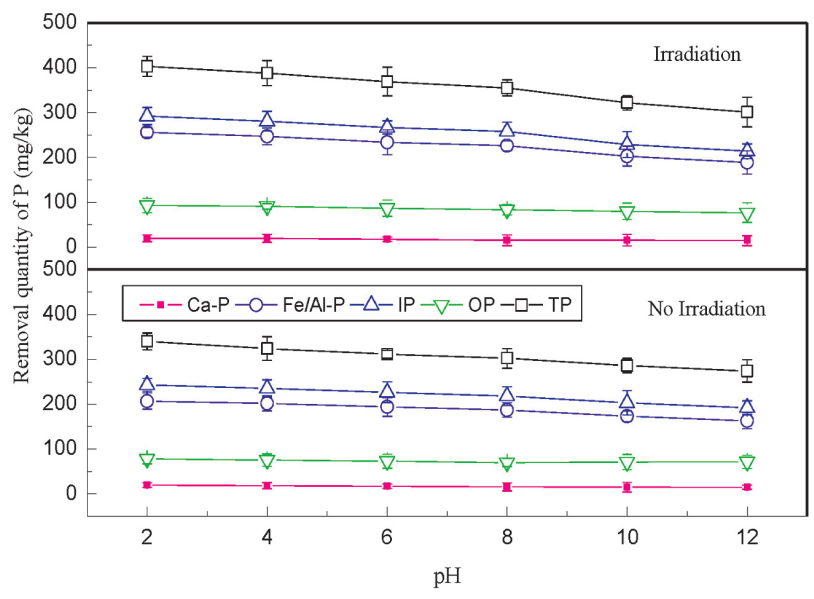

Figure 4: Effect of overlying water $\mathrm{pH}$ on $\mathrm{P}$ removal rises $\left(5-30{ }^{\circ} \mathrm{C}\right)$. Under the adsorption conditions, the removal quantity of each $\mathrm{P}$ forms at $5{ }^{\circ} \mathrm{C}$ was $13 \mathrm{mg} / \mathrm{kg}$, $163 \mathrm{mg} / \mathrm{kg}, 183 \mathrm{mg} / \mathrm{kg}, 54 \mathrm{mg} / \mathrm{kg}$ and $276 \mathrm{mg} / \mathrm{kg}$, respectively. And the removal amount of each $\mathrm{P}$ forms on PCFM at $30{ }^{\circ} \mathrm{C}$ was $16 \mathrm{mg} / \mathrm{kg}, 189 \mathrm{mg} / \mathrm{kg}, 220 \mathrm{mg} / \mathrm{kg}$, $71 \mathrm{mg} / \mathrm{kg}$ and $308 \mathrm{mg} / \mathrm{kg}$, respectively. The adsorption amount of sediment $\mathrm{P}$ was decreased in different degrees as the operation temperature rose $(P<0.05)$. The removal quantity of each $\mathrm{P}$ form at $70{ }^{\circ} \mathrm{C}$ was decreased $5 \mathrm{mg} / \mathrm{kg}, 55 \mathrm{mg} / \mathrm{kg}, 55 \mathrm{mg} / \mathrm{kg}, 18 \mathrm{mg} / \mathrm{kg}$ and $75 \mathrm{mg} / \mathrm{kg}$, respectively.

Under photocatalytic conditions, the removal amount of each $\mathrm{P}$ form at $5{ }^{\circ} \mathrm{C}$ was $13 \mathrm{mg} / \mathrm{kg}, 203 \mathrm{mg} / \mathrm{kg}$, $220 \mathrm{mg} / \mathrm{kg}, 68 \mathrm{mg} / \mathrm{kg}$ and $296 \mathrm{mg} / \mathrm{kg}$, respectively, the corresponding removal rate was $12.4 \%, 43.9 \%, 39.8 \%$, $39.3 \%$ and $38.4 \%$, respectively. When the temperature rose to $30{ }^{\circ} \mathrm{C}$, the removal quantity of each $\mathrm{P}$ form was increased to $17 \mathrm{mg} / \mathrm{kg}, 236 \mathrm{mg} / \mathrm{kg}, 263 \mathrm{mg} / \mathrm{kg}, 85 \mathrm{mg} / \mathrm{kg}$ and $364 \mathrm{mg} / \mathrm{kg}$, respectively, correspondingly, the removal rate was $16.2 \%, 49.8 \%, 47.6 \%, 49.1 \%$ and $47.2 \%$, respectively. Under the adsorption conditions, the removal amounts of all $\mathrm{P}$ forms (except $\mathrm{Ca}-\mathrm{P}$ ) were decreased in varying degrees as the operation temperature rose. It was speculated that the high temperature promotes the desorption process and Brownian motion, thus reducing the efficiency of the photocatalytic reaction.

\subsection{Static adsorption tests}

For further applying to treat the actual lake with Sr-TiO $/$ PCFM, static adsorption tests were carried out with reaction times from $0 \mathrm{~d}$ to $22 \mathrm{~d}$. The related results are shown in Figure 6. The removal amount of each $\mathrm{P}$ form was not apparent after $18 \mathrm{~d}(P<0.05)$. The adsorption quantity of each $\mathrm{P}$ form on $18 \mathrm{~d}$ was $11 \mathrm{mg} / \mathrm{kg}$, $136 \mathrm{mg} / \mathrm{kg}, 154 \mathrm{mg} / \mathrm{kg}, 52 \mathrm{mg} / \mathrm{kg}$ and $218 \mathrm{mg} / \mathrm{kg}$, respectively. Correspondingly, the adsorption rate was $10.5 \%, 29.4 \%, 27.8 \%, 30.1 \%$ and $28.3 \%$, respectively.

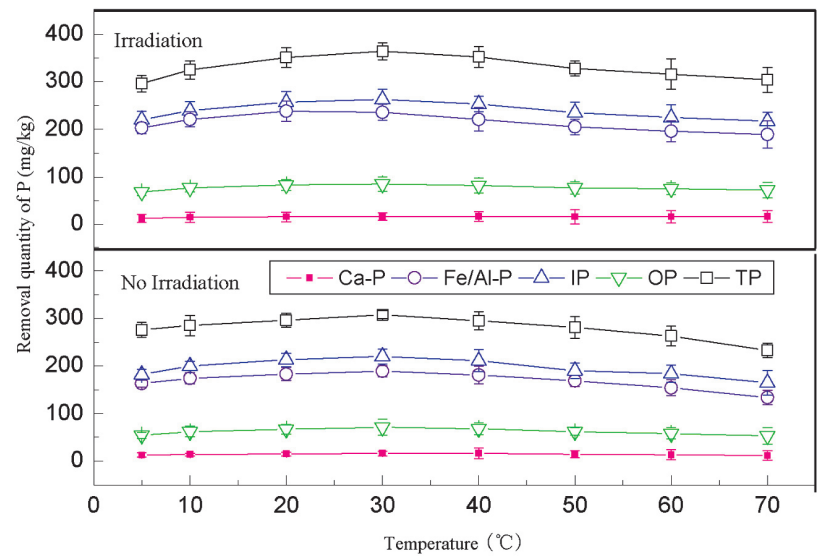

Figure 5: Effect of temperature on $\mathrm{P}$ adsorption 


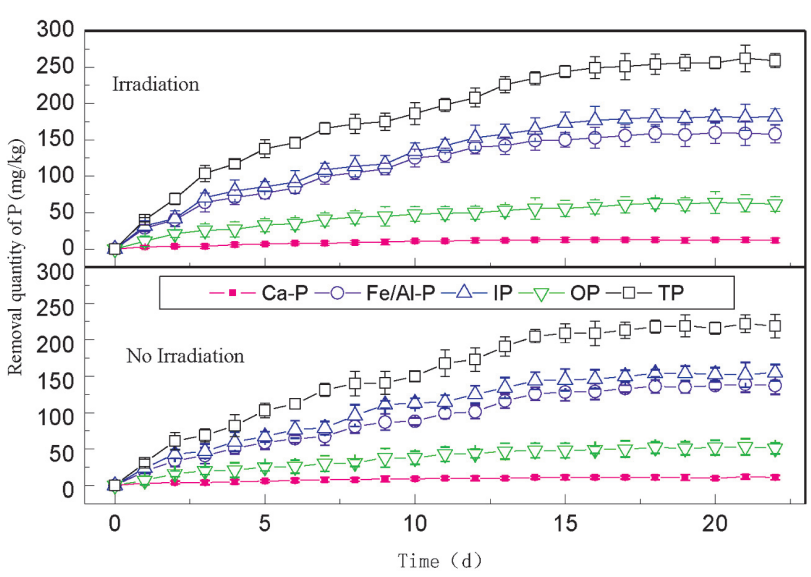

Figure 6: Effect of reaction time of on sediment $\mathrm{P}$ removal

The change trends of each $\mathrm{P}$ form under photocatalytic conditions were similar to that under adsorption conditions, the reaction equilibrium was achieved at $16 \mathrm{~d}$. The removal quantity of each $\mathrm{P}$ forms on $16 \mathrm{~d}$ was $13 \mathrm{mg} / \mathrm{kg}, 159 \mathrm{mg} / \mathrm{kg}, 181 \mathrm{mg} / \mathrm{kg}, 63 \mathrm{mg} / \mathrm{kg}$ and $254 \mathrm{mg} / \mathrm{kg}$, respectively. The corresponding adsorption rate reached $12.4 \%, 34.4 \%, 32.7 \%, 36.4 \%$ and $32.9 \%$, respectively. The sediment $\mathrm{P}$ were reduced efficiently by $\mathrm{Sr}^{-\mathrm{TiO}_{2}} / \mathrm{PCFM}$.

\subsection{The combined effect of $\mathrm{Sr}-\mathrm{TiO}_{2} / \mathrm{PCFM}$ and sub- merged plants}

\subsubsection{Effects of thickness of $\mathrm{Sr}-\mathrm{TiO}_{2} / \mathrm{PCFM}$ on the re-} moval of $T P$

Tests were carried out with different thickness $(1 \mathrm{~cm}$, $2 \mathrm{~cm}, 4 \mathrm{~cm}$ and $6 \mathrm{~cm}$ ) to investigate the effects of the thickness of $\mathrm{Sr}-\mathrm{TiO}_{2} / \mathrm{PCFM}$ on sediment $\mathrm{P}$ removal under irradiation and outdoor (control group) conditions. The results are presented in Figure 7. In outdoor conditions, the removal amount of TP on $120 \mathrm{~d}$ was

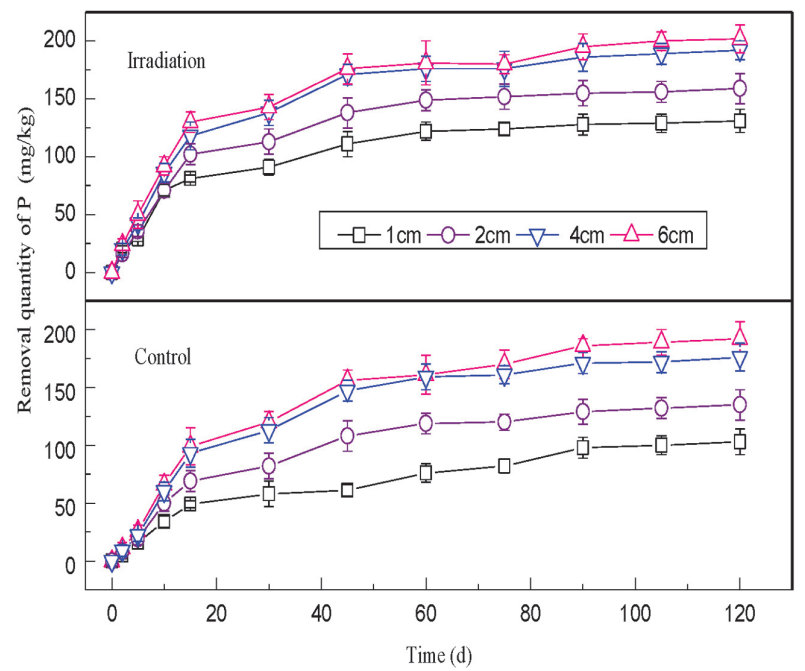

Figure 7: Effect of thickness of $\mathrm{Sr}-\mathrm{TiO}_{2} / \mathrm{PCFM}$ on sediment $\mathrm{P}$ removal

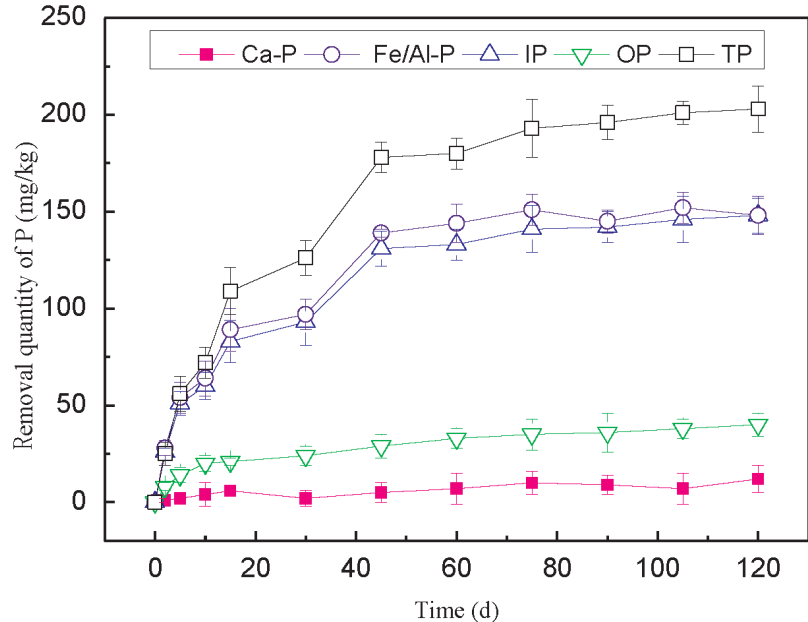

Figure 8: Removal effect of sediment P by Potamogeton crispus

$176 \mathrm{mg} / \mathrm{kg}$ as the thickness was $4 \mathrm{~cm}$, correspondingly, the removal rate was $22.8 \%$. The removal amount of TP at $120 \mathrm{~d}$ added just $16 \mathrm{mg} / \mathrm{kg}$ when the thickness increased to $6 \mathrm{~cm}$. Under irradiation conditions, the removal amount of TP at $120 \mathrm{~d}$ was $192 \mathrm{mg} / \mathrm{kg}$ and $202 \mathrm{mg} / \mathrm{kg}$ as the thickness was $4 \mathrm{~cm}$ and $6 \mathrm{~cm}$, correspondingly, the removal rate was $24.9 \%$ and $26.2 \%$, respectively. It is thus clear that the removal quantity of TP was further improved after irradiation, especially the first $45 \mathrm{~d}$. The $\mathrm{Sr}-\mathrm{TiO}_{2} / \mathrm{PCFM}$ thickness of $4 \mathrm{~cm}$ was selected as the optimal dosage to study the synergistic effect of $\mathrm{Sr}-\mathrm{TiO}_{2} / \mathrm{PCFM}$ and submerged plants on sediment $\mathrm{P}$ removal.

\subsubsection{The combined effect of $\mathrm{Sr}-\mathrm{TiO}_{2} / \mathrm{PCFM}$ and Pota- mogetor crispus}

The removal quantity of sediment $\mathrm{P}$ is presented in Figure 8. The removing rate of Fe/Al-P and IP increased rapidly within $45 \mathrm{~d}$ and then slowly and later flattened at $75 \mathrm{~d}$. The removal quantity of Fe/Al-P, IP, OP and TP by

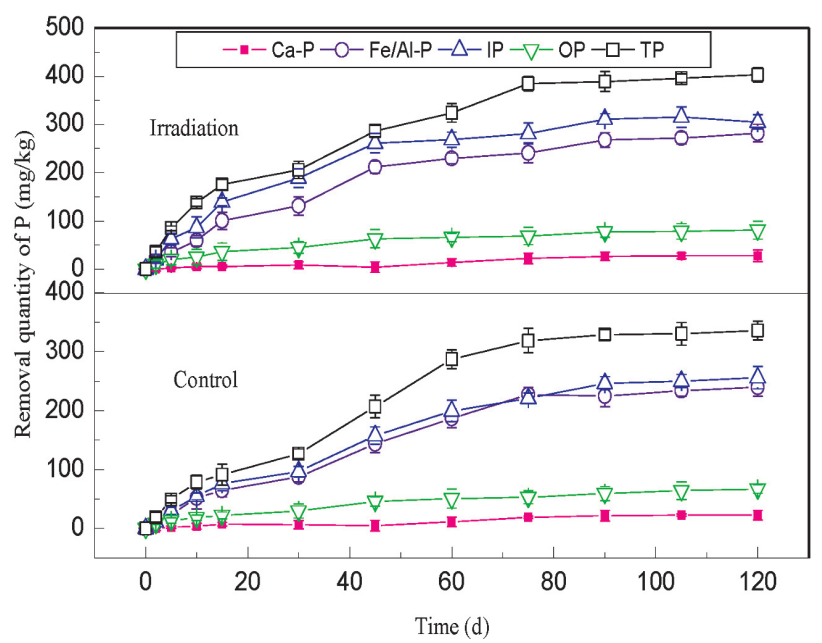

Figure 9: Synergistic effect of Potamogeton crispus and $\mathrm{Sr}-\mathrm{TiO}_{2} /$ PCFM on sediment $\mathrm{P}$ removal 
Potamogetor crispus on $75 \mathrm{~d}$ was $141 \mathrm{mg} / \mathrm{kg}, 151 \mathrm{mg} / \mathrm{kg}$, $35 \mathrm{mg} / \mathrm{kg}$ and $193 \mathrm{mg} / \mathrm{kg}$, respectively.

The synergistic effects of $\mathrm{Sr}-\mathrm{TiO}_{2} / \mathrm{PCFM}$ (thickness $4 \mathrm{~cm})$ and Potamogetor crispus on sediment $\mathrm{P}$ under irradiation and control conditions are presented in Figure 9. The removal quantity of each $\mathrm{P}$ form was $23 \mathrm{mg} / \mathrm{kg}, 240 \mathrm{mg} / \mathrm{kg}, 256 \mathrm{mg} / \mathrm{kg}, 67 \mathrm{mg} / \mathrm{kg}$ and $336 \mathrm{mg} / \mathrm{kg}$, respectively, correspondingly, the removing rate was $21.9 \%, 51.9 \%, 46.3 \%, 38.7 \%$ and $43.6 \%$ in the control group. Under the irradiation conditions, the removal quantity of each $\mathrm{P}$ form reached $28 \mathrm{mg} / \mathrm{kg}$, $282 \mathrm{mg} / \mathrm{kg}, 306 \mathrm{mg} / \mathrm{kg}, 81 \mathrm{mg} / \mathrm{kg}$ and $403 \mathrm{mg} / \mathrm{kg}$, respectively. Correspondingly, the removal rate reached $26.7 \%, 61.0 \%, 55.3 \%, 46.8 \%$ and $52.3 \%$, respectively. It was observed that the removal rates of the sediment $\mathrm{P}$ were further enhanced after irradiation, and the removal amount of each $\mathrm{P}$ forms (except Ca-P) increased obviously more than the control group especially within $60 \mathrm{~d}$.

Through comparing the removal effects of each method, we found that the unity of $\mathrm{Sr}-\mathrm{TiO}_{2} / \mathrm{PCFM}$ and Potamogeton crispus have more remarkable effects on sediment $\mathrm{P}$ removal than the summation of the effect of Sr- $\mathrm{TiO}_{2} / \mathrm{PCFM}$ and Potamogeton crispus applied separately under the irradiation conditions. The probable reasons were that:

1) the irradiation of high-pressure mercury lamp not only enhanced the photocatalytic efficiency, but also increased the biomass of the submerged macrophyte;

2) the residual $P$ forms in the sediment that did not adsorb on the $\mathrm{Sr}-\mathrm{TiO}_{2} / \mathrm{PCFM}$ were changed by Potamogeton crispus through nutrition partitioning and root oxygenation, and then the adsorption of residual $\mathrm{P}$ on $\mathrm{Sr}-\mathrm{TiO}_{2} / \mathrm{PCFM}$ was promoted; ${ }^{26}$

3 ) the growth of Potamogeton crispus was also accelerated owing to the trace elements contained in Sr- $\mathrm{TiO}_{2} / \mathrm{PCFM}$;

4) the mineralization process of the sediment was promoted with the help of micro-organisms on $\mathrm{Sr}_{-} \mathrm{TiO}_{2} / \mathrm{PCFM}$, thus the bioavailability by Potamogeton crispus was further enhanced.

\section{CONCLUSIONS}

The control effect of each $\mathrm{P}$ form in an eutrophic lake with the synergistic effect of $\mathrm{Sr}-\mathrm{TiO}_{2} / \mathrm{PCFM}$ and Potamogeton crispus was studied for the first time. The main contributions of this work are as follows:

1) The compact nano-Sr- $-\mathrm{TiO}_{2}$ film firmly loaded on the surface of the PCFM, and the average particle size of $\mathrm{TiO}_{2}$ was 10-20nm.

2) $\mathrm{Sr}-\mathrm{TiO}_{2} / \mathrm{PCFM}$ dosage, reaction time, irradiation, operation temperature and $\mathrm{pH}$ were the principal factors affect the removal of sediment $\mathrm{P}$ by $\mathrm{Sr}-\mathrm{TiO}_{2} / \mathrm{PCFM}$.

3) The removal amount of each $P$ form in the sediment under the optimal photocatalytic conditions was $20 \mathrm{mg} / \mathrm{kg}, 256 \mathrm{mg} / \mathrm{kg}, 292 \mathrm{mg} / \mathrm{kg}, 93 \mathrm{mg} / \mathrm{kg}$ and 403 $\mathrm{mg} / \mathrm{kg}$, respectively. Under the optimal photocatalytic conditions of static tests, the removal amount at $16 \mathrm{~d}$ was $13 \mathrm{mg} / \mathrm{kg}, 159 \mathrm{mg} / \mathrm{kg}, 181 \mathrm{mg} / \mathrm{kg}, 63 \mathrm{mg} / \mathrm{kg}$ and 254 $\mathrm{mg} / \mathrm{kg}$, respectively.

4) The effect of the combination of $\mathrm{Sr}-\mathrm{TiO}_{2} / \mathrm{PCFM}$ and Potamogetor crispus on sediment $\mathrm{P}$ in all fractions under irradiation and control conditions showed that the removal rates of each $\mathrm{P}$ form were further enhanced after irradiation. The combination of $\mathrm{Sr}-\mathrm{TiO}_{2} / \mathrm{PCFM}$ and Potamogeton crispus demonstrated the higher removal effect of sedimental $\mathrm{P}$ than the summation of $\mathrm{Sr}-\mathrm{TiO}_{2} /$ PCFM and Potamogeton crispus applied separately under the irradiation conditions.

\section{Funding}

This work was supported by National Natural Science Foundation of China (No. 51709254), Youth Innovation Promotion Association, Chinese Academy of Sciences (No. 2020335) and Zhejiang Provincial Natural Science Foundation of China (No. LY18E080005).

\section{Acknowledgment}

We thank Drs. Qiaohong Zhou, Enrong Xiao and Ms. Liping Zhang for the experimental design and paper preparation.

\section{REFERENCES}

${ }^{1}$ J. Lin, Q. Sun, S. Ding, D. Wang, Y. Wang, M. Chen, L. Shi, X. Fan, D. C. W. Tsang, Mobile phosphorus stratification in sediments by aluminum immobilization, Chemosphere, 186 (2017), 644-651

${ }^{2}$ C. W. Lü, B. Wang, J. He, R. D. Vogt, B. Zhou, R. Guan, L. Zuo, W. Wang, Z. Xie, J. Wang, D. Yan, Responses of organic phosphorus fractionation to environmental conditions and lake evolution, Environ. Sci. Technol., 50 (2016), 5007-50

${ }^{3}$ T. H. Kim, J. H. Kang, S. H. Kim, I. S. Choi, K. H. Chang, J. M. Oh, K. H. Kim, Impact of salinity change on water quality variables from the sediment of an artificial lake under anaerobic conditions, Sustainability, 9 (2017), 1429

${ }^{4}$ J. Kopáček, J. Borovec, J. Hejzlar, K. U. Ulrich, S. A. Norton, A. Amirbahman, Aluminum control of phosphorus sorption by lake sediments, Environ. Sci. Technol., 39 (2005), 8784-8789

${ }^{5}$ Y. Zhang, F. He, S. Xia, Q. Zhou, Z. Wu, Studies on the treatment efficiency of sediment phosphorus with a combined technology of PCFM and submerged macrophytes, Environ. Pollut., 206 (2015), 705-711

${ }^{6}$ S. Chen, S. Wang, C. Wu, Sediment removal efficiency of siphon dredging with wedge-type suction head and float tank, Int. J. Sediment. Res., 25 (2010), 149-160

${ }^{7}$ R. Devesa-Rey, N. Fernández, J. M. Cruz, A. B. Moldes, Optimization of the dose of calcium lactate as a new coagulant for the coagulation-flocculation of suspended particles in water, Desalination, 280 (2011), 63-71

${ }^{8}$ K. Reitzel, J. Hansen, F. O. Andersen, K. S. Hansen, H. S. Jensen, Lake restoration by dosing aluminum relative to mobile phosphorus in the sediment, Environ. Sci. Technol., 39 (2005), 4134-4140

${ }^{9}$ M. Yang, J. Lin, Y. Zhan, Z. Zhu, H. Zhang, Immobilization of phosphorus from water and sediment using zirconium-modified zeolites, Environ. Sci. Pollut. Res., 22 (2015), 3606-3619 
${ }^{10}$ H. K. Kwon, S. J. Oh, H. S. Yang, Growth and uptake kinetics of nitrate and phosphate by benthic microalgae for phytoremediation of eutrophic coastal sediments, Bioresour. Technol., 129 (2013), 387-395

${ }^{11}$ T. Péter, W. Chin, Temperature and Circulation Dynamics in a Small and Shallow Lake: Effects of Weak Stratification and Littoral Submerged Macrophytes, Water., 1 (2019) 11, 128, doi:10.3390/ w11010128

${ }^{12}$ C. Wang, Y. Qi, Y. Pei, Laboratory investigation of phosphorus immobilization in lake sediments using water treatment residuals, Chem. Eng. J., 209 (2012), 379-385

${ }^{13}$ H. Yin, K. Ming, Reduction of sediment internal P-loading from eutrophic lakes using thermally modified calcium-rich attapulgite-based thin-layer cap, J. Environ. Manage, 151 (2015), 178-185

${ }^{14}$ Y. Zhang, C. Wang, F. He, B. Liu, D. Xu, S. Xia, Q. Zhou, Z. Wu, In-situ adsorption-biological combined technology treating sediment phosphorus in all fractions, Sci. Rep., 6 (2016), 29725

${ }^{15}$ R. Vinu, G. Madras, Kinetics of simultaneous photocatalytic degradation of phenolic compounds and reduction of metal ions with nano- $\mathrm{TiO}_{2}$, Environ. Sci. Technol., 42 (2008), 913-919

${ }^{16}$ S. Lorencik Q. Yu, H. J. H. Brouwers, Photocatalytic coating for indoor air purification: Synergetic effect of photocatalyst dosage and silica modification, Chem. Eng. J., 306 (2016), 942-952

${ }^{17}$ M. Wang, B. Gao, D. Tang, Review of key factors controlling engineered nanoparticle transport in porous media, J. Hazard. Mater., 318 (2016), 233-246

${ }^{18}$ M. Tasbihi, K. Kočí, I. Troppová, M. Edelmannová, M. Reli, L. Čapek, R. Schomäcker, Photocatalytic reduction of carbon dioxide over $\mathrm{Cu} / \mathrm{TiO}_{2}$ photocatalysts, Research Environ. Sci. Pollut., 25 (2017), 34903-34911
${ }^{19}$ Y. Zhang, F. He, D. Kou, D. Xu, S. Xia, Z. Wu, Adsorption of sediment phosphorus by porous ceramic filter media coated with nano-titanium dioxide film, Ecol. Eng., 64 (2014), 186-192

${ }^{20}$ V. Ruban, J. F. Lopez-Sanchez, P. Pardo, G. Rauret, H. Muntau, P. Quevauviller, Harmonized protocol and certified reference material for the determination of extractable contents of phosphorus in freshwater sediments-a synthesis of recent works, Fresenius. J. Anal. Chem., 370 (2001), 224-228

${ }^{21}$ Y. Zhang, Y. Shao, N. Gao, Y. Gao, W. Chu, S. Li, Y. Wang, S. Xu, Kinetics and by-products formation of chloramphenicol (CAP) using chlorination and photocatalytic oxidation, Chem. Eng. J., 333 (2018), 85-91

${ }^{22}$ R. Rezaei, M. Mohseni, Impact of $\mathrm{pH}$ on the kinetics of photocatalytic oxidation of 2,4-dichlorophenoxy acetic acid in a fluidized bedphotocatalytic reactor, Applied Catalysis B: Environmental, 205 (2017), 302-309

${ }^{23}$ S. Maeng, K. Cho, B. Jeong, J. Lee, Y. Lee, C. Lee, K. J. Choi, S. W. Hong, Substrate-immobilized electrospun $\mathrm{TiO}_{2}$ nanofibers for photocatalytic degradation of pharmaceuticals: The effects of $\mathrm{pH}$ and dissolved organic matter characteristics, Water. Res., 86 (2015), 25-34

${ }^{24}$ J. Zhang, X. Huang, Effect of temperature and salinity on phosphate sorption on marine sediments, Environ. Sci. Technol., 45 (2011), 6831-6837

${ }^{25}$ S. Jellali, M. A. Wahab, R. B. Hassine, A. H. Hamzaoui, L. Bousselmi, Adsorption characteristics of phosphorus from aqueous solutions onto phosphate mine wastes, Chem. Eng. J., 169 (2011), $157-165$

${ }^{26}$ S. Wang, L. Jiao, S. Yang, X. Jin, W. Yi, Effects of organic matter and submerged macrophytes on variations of alkaline phosphatase activity and phosphorus fractions in lake sediment, J. Environ. Manage, 113 (2012), 355-360 